\title{
PIEDERĪBAS IZJŪTA UN ATGRIEŠANĀS PLĀNI: KAS MAINĪJIES LATVIJAS DIASPORĀ?
}

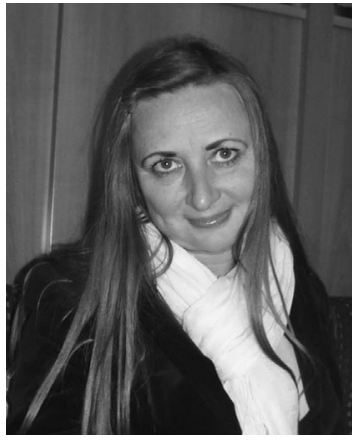

Ilze Koroḷeva, Dr. sc. soc., ir LU Filozofijas un sociologijas institūta direktora vietniece un vadošā pētniece. Ieguvusi sociologíijas doktora grādu LU Sociālo zinātnuu fakultātē (2011). Vadījusi vairākus lielus ES pētnieciskos projektus Latvijā, piem., Path of the Generation, EUROSTUDENT, ESPAD, European Social Survey (ESS), kā pētniece piedalījusies daudzos starptautiskos projektos, tai skaitā FP7 Memory, Youth, Political Legacy and Civic Engagement (MYPLACE), FP7 Measuring Youth Well-Being (MYWEB), H2020 Cultural Heritage and Identities of Europe's Future (CHIEF) un citos. Zinātniskās publikācijas žurnālos The Sociological Review, European Psychiatry, Religious-Philosophical Articles. Saṇēmusi LZA Tālivalža Vilciņa vārdbalvu sociolog̣ijā (2016).
Raksturvārdi: migrācija, piederības izjūta, piederības apziņas dimensijas.

\section{Ievads}

Globālie procesi, ko pavada brīva cilvēku kustība un mūsdienu tehnologiiskās iespējas, kas ḷauj mums dažu sekunžu laikā iegūt informāciju no visas pasaules vai dažu stundu laikā aizcelotot, pat pārcelties uz dzīvi citā valstî, nokḷūt pavisam atšķirīgā kultūras un valodas vidē, liek mums aizvien biežāk sev uzdot un noskaidrot jautājumu, kas es esmu, kam justies piederīgam; noteikt, kas ir kopējs "mums" un "viniiem", novilkt robežas starp "savējiem" un "citiem". N̦emot vērā emigrācijas plūsmu pastiprināšanos, arī Latvijas diasporas piederības jūtu un identitātes teorētisko un empīrisko aspektu analīzei tiek pievērsta padzilināta uzmanība. ${ }^{1}$

Piederība un migrācija, līdzīgi kā nacionālisms un globalizācija, sākotnēji ietver šķietamu pretrunu. Piederības jēdziena operacionalizācija

1 Sk. Ķešāne 2011; Lulle 2011; Bela 2014 u. c. nacionālās identitātes un ierobežotas teritorijas kontekstā asociējas ar tādiem jēdzieniem kā "iesakņotība", "miera stāvoklis", "līdzsvars", "tradicionālisms", turpretim "migrācija" saistīta ar mobilitāti un postmodernitāti, globalizāciju pavadošo robežu nosacītību, nenoteiktību. Piederības un identitātes jēdziens migrācijas un diasporas pētījumos iegūst jaunu kontekstu un nozīmi, kas prasa arī atškirīgu konceptuālo pieeju. ${ }^{2}$ Pēdējo desmitgažu laikā šīs pieejas ir mainījušās, pārnesot galveno akcentu uz darbību, individuālās aktivitātes un izvēles nozīmi.

Pieejas identitātes analīzē balstîtas uz vairākiem kopīgiem pieņēmumiem: tās attīstās sociālā kontekstā, tās veido kultūra, laiks un vietas apstākḷi, identitātes tiek aplūkotas kā dzīves gājuma projekti, atzīstot, ka šis process nekad nebeidzas; identitātes attīstās dažādos veidos, kas var pārklāties un konfliktēt, balansējot starp indivīda nepieciešamību piederēt, iekḷauties grupā un nepieciešamību būt atšķirīgam. Kvīnslendas Universitātes profesors Metjū Hornsijs (Matthew Hornsey), apkopojot

2 Hedetoft 2004, 24. 
teorētiskās pieejas identitātes pētniecībā, aplūko dažādās stratēgijas, kā cilvēki līdzsvaro savu vajadzību piederēt, iekḷauties sociālajās grupās ar nepieciešamību būt atšķirīgam. ${ }^{3}$ Piederība nav kas tāds, ko cilvēks vienreiz piefiksē un patur uz visiem laikiem. Jo pasaule, kurā mēs dz̄ivojam, un cilvēki, ieskaitot mūs pašus, ir nemit̄̄gi main̄̄gi un piederība ir kaut kas, ko mēs saglabājam kā sasniegtu caur aktīvu procesu. Citiem vārdiem, piederību var attēlot kā trajektoriju laikā un telpā. ${ }^{4}$

Migrācijas kontekstā (tā saistīta ar fizisku pārvietošanās procesu un to, ka indivīdam aizvien no jauna jādefinē sava identitāte ${ }^{5}$ ) īpaši tiek pasvītrots identitātes dinamiskais aspekts, saprotot to drīzāk kā konstruējamu fenomenu, kas laika gaitā un atkarībā no vietas ir mainīgs, nevis fiksēts vai statisks ${ }^{6}$.

Pārceļoties uz dz̄̄vi citā valstī, imigrants bieži internalizē jaunu nacionālo identitāti (psiholog̣iskā akulturācija), lai arī tas nozīmē identificēšanos ar kultūru, kuras vērtības un tradīcijas lielākoties atšķiras no viņa izcelsmes valsts kultūras vērtībām. Veiksmīga internalizācijas procesa rezultātā indivīdam veidojas jauna nacionālā identitāte, un šis process tiek saistīts ar veiksmīgu integrāciju. ${ }^{7}$ Tas gan nenozīmēe, ka indivīds atsakās vai vinam būtu jāatsakās no iepriekšējās identitātes.

Identificēšanās procesu, ne tik daudz identitāti kā š̀ procesa rezultātu vairāk palīdz atklāt piederības izpēte, bet abi šie aspekti ir cieši saistīti un ikdienas apziņā grūti nošķirami. Rakstā izmantotā empīriskā materiāla ietvaros ārpus Latvijas dzīvojošo Latvijas valstspiederīgo identitātes raksturojumi gūti, balstoties uz piederības ciešuma mērījumiem, kas lietoti, lai noskaidrotu gan piederību sociālajām grupām, kopienai, gan vietai, konkrētai teritorijai. Piederība nozīmē indivīda identificēšanos ar noteiktu kopienu, un otrādi - kopiena konstruē un apzinās sevi kā individuālo piederību kopumu. ${ }^{8}$ Kā norāda Mančestras

3 Hornsey, Jetten 2004.

4 De Certeau 1984.

5 Frideres 2002.

6 Sk. Bokser-Liwerant 2002; Rummens 2001; Rashid 2007 u. c.

7 Grant 2007; Baffoe 2011.

8 Hedetoft 2004.
Universitātes pētniece Vanesa Meja (Vannesa May), piederības jēdziens tiek izmantots, lai pêtītu attiecības starp patību (self) un sabiedrību vairāku aspektu dēḷ: pirmkārt, tas ir uz personu vērsts, otrkārt, tas tiek lietots ikdienā, kur savijas formālās un neformālās attiecības, sfēras, treškārt, tas ḷauj kompleksi skatīt patības un sabiedrības attiecības, un, ceturtkārt, šo attiecību dinamika l̦auj fiksēt sociālas pārmaiņas. ${ }^{9}$

Piederības izjūtas var būt stiprākas vai vājākas, ciešas vai mazāk ciešas, tas padara iespējamus šo izjūtu intensitātes kvantitatīvus mērījumus. Minēto aspektu dēl piederības pieeju plaši izmanto socioloǵiskajos pētījumos, t. sk. migrācijas jomā. Arī Latvijā dažādu mērķgrupu, jo īpaši jauniešu, identitātes pētījumos šî pieeja izmantota vairākkārt. ${ }^{10}$

Kopenhāgenas Universitātes profesors Ulfs Hedetofts (Ulf Hedetoft) norāda uz četriem piederības analīzes aspektiem, kuri dažādos veidos nosaka identitāti, - piederības avots; piederības izjūta (ko veido sociālpsiholoǵiskās vajadzības, identificēšanās ar vietu un atminas); piederības konstruěšana un institucionalizācija; piederības main̄̄gums, atzīmējot visu šo aspektu savstarpējo saistību piederības apziņas izveidē. Piederības jūtas nekad nav nepastarpinātas vai patiesi "tīras", tās vienmēr iziet caur mentālu procesu, personisko un kolektīvo pieredzi, laika posmu un psihologiskiem filtriem, katrs no tiem veido individuālo piederības tēlu un uztveri. Tā veidojas arī jaunas piederības formas emigrācijā - mijiedarbībā ar atmiṇām, pieredzi, nākotnes plāniem, iespējām. ${ }^{11}$

Gan dzīvi Latvijā, gan emigrācijā var aplūkot kā piederības veidošanās avotu. Bet piederības izjūtu veidošanās process ir pietiekami komplicēts, nereti iekšēji konfliktējošs. Cilvēks, kas atstājis savu dzimteni un pārcēlies uz dzìvi citā valstī, meklē jaunus piederības objektus, veidojas jaunas piederības jūtas kā vietām, tā grupām mītnes zemēs, pārvarot iekšējās pretrunas starp vēlmi būt līdzīgiem un piederēt citiem un vienlaikus vēlmi palikt

\footnotetext{
9 May 2011, 364.

${ }^{10}$ Koroḷeva, Rungule 2013; Rungule, Koroḷeva 2014 u. c.

${ }^{11}$ Hedetoft 2004, 24.
} 
unikālam un atškikirīgam no citiem. Šis ceḷš ir individuāls, un migrantu piederību vienmēr var uztvert kā "pārāk ciešu vai pārāk vāju" identifikāciju, kas nekad nesasniedz perfektu līdzsvaru starp piederību izcelsmes valsts un uzņemošās valsts kopienai. ${ }^{12}$ Piederība grupai, vietai sniedz ontoloǵisko drošības sajūtu, un, kā atzīmē Vanesa Meja, piederības konceptam lielākoties ir pozitīva konotācija. Piederība tiek izprasta kā izjūta, kas atvieglo indivīda sadzīvošanu ar apkārtni, bet nepiederība neizbēgami var tikt raksturota kā apgrūtinoša. ${ }^{13}$ Neidentificēšanās ar vietu tāpat var atstāt negatīvas sekas, radot cilvēkam atsvešinātības un tukšuma izjūtu. Tā veicina ilgas pēc mājām, depresiju, pamestības sajūtu. No otras puses, tas var būt iemesls lēmumam atgriezties.

Piederības jūtu veidošanās un transformācijas emigrācijā ir ḷoti nozīmīgs izpētes priekšmets arī tādēl, ka piederības jūtu saglabāšanās pret izcelsmes valsti un jaunu jūtu veidošanās mītnes zemē lielā mērā ietekmē cilvēka lēmumu palikt tur vai atgriezties.

Š̀ raksta galvenais mērḳis ir analizēt piederības apziņu dažādās Latvijas emigrantu grupās un, balstoties uz longitudināliem datiem, noskaidrot faktorus, kas piecu gadu laikā individuālā līmen̄i ietekmējuši izmaiņas piederības izjūtās. ${ }^{14}$

Migrācijai veltîtajā literatūrā norādīts uz virkni faktoru, kas var ietekmēt migrantu piederības jūtas, identitātes transformācijas un jaunu identitāšu veidošanos. To starpā visbiežāk tiek minēts uzṇemošajā valstī pavadītais laiks, oficiāla pilsonības iegūšana, izcelsmes vai galamērka valsts kultūras atbilstības vai nesaderības pakāpe un pieredze uznēēmējvalsts sabiedrībā. ${ }^{15}$ Akcentējot piederības jūtu un identitātes apzināšanās emocionālo aspektu, tiek uzsvērta ǵimenes (jēdziena visplašākajā nozīmē ietverot attiecības un saikni ar bērniem, vecākiem un paša indivīda ǵimenes locekliem, ǵimenes

12 Hall 1996.

13 May 2011, 373.

14 Raksts izstrādāts Latvijas Zinātnes padomes (LZP) granta Labklājības un sociālās integrācijas izpēte likvīdās migrācijas kontekstā: longitudinālà pieeja (Nr. LZP-2018/1-0042) ietvaros.

15 Krzyzanowskli, Wodak 2007; Grant 2007. izveidi utt.) loma un draugi kā izcelsmes, tā arī uzņemošajā valstī.

Koncentrējoties uz ǵimenes pieredzi, Stratklaidas Universitātes profesore Daniela Sime (Daniela Sime) analizē spriedzi, ko migrācija rada ǵimenes attiecībās, emocionālos traucējumus un draudus indivīda piederības izjūtai un ontoloǵiskajai drošībai, vienlaikus uzsverot šīs iekšējās (ne)drošības, kuras uztvere laika gaitā mainās atkarībā no gímenes apstākḷiem, nepastāvīgumu. ${ }^{16}$ Pētnieki norāda uz to, cik trausls ir līdzsvars starp ekonomiskajiem ieguvumiem migrācijas rezultātā un "upuriem”, uz emocionālo samaksu, kas visbiežāk tiek identificēta ar kontaktu zaudēšanu ar bērniem un gimenes locekḷiem, uz sociālā atbalsta tīklu zudumu, ${ }^{17}$ kas viennozīmīgi ietekmē indivīda apmierinātību, subjektīvās labklājības līmeni.

Pamatojoties uz iepriekš aplūkotajiem teorētiskajiem atzinumiem un citu pētījumu rezultātiem, šajā rakstā pārbaudei tiek izvirzītas divas hipotētisku pieņēmumu kopas:

- piederības jūtu veidošanos un intensitāti, kā arī izmaiņas piederības apziņā nosaka šādi objektīvie faktori: emigrācijā pavadītais laiks, izcelıošanas laiks (emigrācijas vilnis), nodarbošanās mītnes zemē, demogrāfiskās pazīmes, sociālās saites: ğimene un draugi Latvijā un ārzemēs, îpašums Latvijā;

- piederības izjūtu stiprums atkarīgs no šādiem subjektīvajiem faktoriem: apmierinātība ar dažādiem dzīves aspektiem, uzticēšanās.

\section{Dati un metodes}

Piederības apzinasas analīze balstīta uz unikāliem empīriskiem materiāliem, ko nodrošina Latvijas emigrantu un remigrantu longitudinālā pētījuma divu posmu kvantitatīvo aptauju dati: pētījuma pirmais vilnis jeb ārpus Latvijas dzīvojošo latviešu un Latvijas valstspiederīgo bāzes aptauja, kas realizēta 2014. gadā Eiropas Sociālā fonda (ESF) granta Latvijas emigrantu kopienas: nacionālā identitāte, transnacionālās attiecības un diasporas politika ietvaros, un pētījuma otrā viḷna aptauja, kas veikta

\footnotetext{
16 Sime 2018.

17 Skrbiš 2008; Slime 2018 u. c.
} 
2019. gadā Latvijas Zinātnes padomes (LZP) granta Labklājības un sociālās integrācijas izpēte likvīdās migrācijas kontekstā: longitudinālā pieeja $a^{18}$ ietvaros. Pēdējais vilnis iekḷauj gan ārpus Latvijas dzīvojošo, gan remigrantu pētījuma izlasi. Šajā analīzē tiek izmantotas tikai to respondentu atbildes, kuri piedalījušies gan 2014. gada, gan 2019. gada aptaujā $\left(n=1073\right.$, svaroti dati $\left.{ }^{19}\right)$. Tieši longitudinālie dati Latvijā pirmo reizi sniedz pētniekiem iespēju izsekot līdzi piederības apziņas transformācijām ne tikai atsevišksās emigrantu grupās, bet arī individuālā līmeñ̄.

Datu turpmākā analīze un tai izvēlētās metodes izriet no pārbaudei izvirzìtajiem hipotētiskajiem pieñēmumiem. Piederības pazīmju (piederība 10 sociālām un teritoriālām grupām) mērīšanai abos pētījuma posmos tika izmantota 5 punktu vērtējumu skala (kategorijas: loti piederīgs, zināmā mērā piederīgs, nepiederīgs, ne nepiederīgs, samērā nepiederīgs, pilnībā nepiederīgs). Savukārt piederība vietai/teritorijai tika mērīta četru punktu skalā, nosakot piesaistes ciešumu (kategorijas: loti cieši saistīts, cieši saistīts, ne pārāk cieši, nemaz nejūtas saistīts).

Lai uzskatāmāk raksturotu dažādas identitātes dimensijas emigrantu kopienā šobrīd, tika veikta klasteranalīze (izmantojot k-vidējo saistības klasteru apvienošanas metodi), kas palīdz sagrupēt daudzveidīgos mērìjumus un l̦auj definēt iekšêji homogēnas tipoloǵiskas grupas emigrantu kopienā atbilstoši vienu vai otru piederības izjūtu dominancei individuālajā apziņā. Līdzīgos nolūkos klasteranalīze tika izmantota arī 2014. gada aptaujas datu analīzē. Iegūtie rezultāti ḷāva secināt, ka piederības jūtas atkarībā no to ciešuma intensitātes pakḷaujas tipolog̣izācijai, proti, grupējas, veidojot noteiktas piederības apziņas dimensijas. Tādēl šī pati metode tika izmantota arī šoreiz. Analizējot klasifikācijas procedūrā iegūtā rezultējošā mainīgā (respondentu piederība noteiktai grupai) saites ar mainīgajiem, kurus nosaka

18 LZP grants (Nr. LZP-2018/1-0042).

19 Dati svaroti, pielīdzinot paneḷa sadalījumu 2014. g. populācijai, reizinot ar logit regresijā iegūtās panelī palikšanas varbūtības apgriezto lielumu. Sīkāk par datu svarošanu emigrantu aptaujā sk. Goldmanis 2015. hipotēzes, emigrantu piederības apziņas grupas tiek raksturotas atbilstoši dažādām sociāldemogrāfiskām pazīmēm. Pazīmju savstarpējo atkarību noteikšanai tika izmantotas korelāciju tabulas un standarta rezidiju (residuals) aprēkini. ${ }^{20}$

Piederības izjūtu izmaiņu novērtējumam aprēḳināts jauns mainīgais - piederības jūtu indekss, kas individuālā līmenī raksturo izmaiņas vai stabilitāti piecos gados starp diviem aptaujas posmiem un iekḷauj četras kategorijas: (1) vājinājusies piederības izjūta noteiktām sociālajām grupām un vietai (tagad respondents jūtas mazāk piederīgs tām nekā pirms pieciem gadiem); (2) saglabājas vienādi vāja piederība noteiktām sociālajām grupām vai vietai; (3) pastiprinājušās piederības izjūtas (tagad respondents jūtas ciešāk piederīgs kādai grupai vai vietai); (4) saglabājas vienādi stipras piederības izjūtas noteiktām grupām vai vietai. Turpmākai analīzei tika aprēḳināti jauni mainīgie, kas raksturo piederības izjūtu vājināšanos vai pastiprināšanos (1) Latvijai kopumā un vietai, kur respondents dzīvoja pirms izceḷošanas, Latvijas iedzīvotājiem kopumā un ārzemēs dzīvojošajiem izceḷotājiem no Latvijas, (2) vietai, kur respondents šobrīd dzīvo, un mītnes zemei kopumā, mītnes zemes un visas pasaules iedzīvotājiem.

Piederības izjūtu izmaiṇu raksturojumam aprēḳinātās pazīmes kā atkarīgi mainīgie tika iekḷautas loǵistiskās regresijas modeḷos. Lai noteiktu demogrāfisko, sociālo un ekonomisko faktoru ietekmi uz šìm izmaiņām, tika aprēḳināti arī jauni binārie un kategoriālie main̄̄gie šādām neatkarīgajām pazīmēm: (1) sociāli demogrāfiskajiem raksturojumiem - respondenta dzimums, vecums, tautība, izglìtības līmenis, pašreizējās nodarbinātības statuss, mājsaimniecības sastāvs, materiālās pārticības novērtējums; (2) emigrācijas pieredzei - emigrācijā pavadītais laiks, emigrācijas vilnis; (3) sociālo tīklu raksturojumam - ǵimenes locekḷi vai draugi, kas dzīvo ārzemēs, ǵimenes locekḷ̣i

20 Residuals - starpība starp novēroto un teorētiski sagaidāmo biežumu, dalīta ar sagaidāmo standarta novirzi; asresid - pievienotās atlikumvērtības koeficients. Ja korigēetais standarta rezidijs - adjusted standardized residuals - ir $>1,96$ vai $<1,96$, tad pastāv nozīmīgas atšksirības starp pazīmes sadalījumu pētāmajās grupās. 
vai draugi, kas dzīvo Latvijā; (4) līdzdalībai diasporas organizācijās; (5) subjektīvajiem vērtējumiem - apmierinātība ar dažādām dz̄̄ves jomām, uzticēšanās Latvijas valdībai.

Atsevišksi regresijas model̦i tika aprēḳināti trim piederības izmaiņu kategorijām. Regresijas modelī secīgi tika pievienoti neatkarīgo mainīgo bloki, lai noteiktu, kādā mērā šie mainīgie palīdz izskaidrot izmainas piederības izjūtās, t. i., identificēt faktorus, kas ietekmē respondenta piederības jūtu ciešuma vājināšanos vai pastiprināšanos pret visu latvisko vai citādo.

\section{Analīzes rezultāti un to interpretācija}

Vispirms kopējam ieskatam īsa atsauce uz respondentu atbilžu procentuālo sadalījumu piederības mērījumos 2014. un 2019. gadā, kā arī uz piederības izjūtu izmaiņām individuālā līmenī. Šajā rakstā tiek atspogulotas tikai tās piederības pazīmes, kuras raksturo nacionālo vai transnacionālo identitāti, jo, līdzīgi kā citi pētījumi, arī emigrantu pētījuma dati apliecina, ka cilvēki visciešāk jūtas piederīgi sev tuvākajām sociālajām grupām - ǵimenei (apm. 93\%), draugiem (apm. 85\%). Šajās piederības izjūtās neatkarīgi no emigrācijas pieredzes piecu gadu laikā nav vērojamas gandrīz nekādas izmaiņas. Citādi tas ir ar piederību lielākām sociālajām kopienām, kā, piem., savas tautības cilvēkiem, Latvijas, mītnes zemes, Eiropas vai pasaules iedzīvotājiem. 1. tabulā atspoguḷots piederības izjūtu ciešums 2014. un 2019. gadā, apvienojot piederības mērījuma kategorijas "loti piederīgs" un "zināmā mērā piederīgs", bet šīs tabulas 3. un 4. kolonna atspogulo piederỉbas izjūtu vājināšanos vai pastiprināšanos individuālā līmenī.

Aplūkojot datus, jāsecina, ka emigrantu kopā mazinājusies piederības izjūta visam latviskajam. ${ }^{21}$ Piederības jūtas Latvijai mazinājušās no $68 \%$ līdz 59\%, vietai, no kuras izceḷoja, - no 79\% līdz 70\%. Šobrīd grūti skaidrojams, kādēl longitudinālajā izlasē tik

21 Jēdziens "piederība latviskajam” šeit lietots loti plašā nozīmēe, ar to saprotot kā piederību vietai Latvijā, no kuras izcelıts, vietai, kur pavadīta bērnība Latvijā, tā arī piederību latviešiem, no Latvijas izceḷojušajiem cilvēkiem. nozīmīgi sarukusi piederības izjūta savas tautības cilvēkiem. Savukārt pēdējo piecu gadu laikā nozīmīgi ir pieaugusi respondentu piederība šì brīža dzīvesvietai mītnes zemē (no $47 \%$ līdz 60\%), vēl vairāk - mītnes zemes iedzīvotājiem (no 48\% līdz 63\%), kā arī tuvākās apkaimes iedzīvotājiem (no 44\% līdz 68\%).

Izmaiņas ne tikai atspoguḷ svārstības piederības vērtējumos individuālā līmenī, bet ḷauj novērtēt kopējo tendenci - piederība Latvijai, Latvijas iedzīvotājiem un visam latviskajam biežāk ir vājinājusies nekā pastiprinājusies. Savukārt, runājot par mītnes zemi, nozīmīgas pozitīvas izmaiņas vērojamas attieksmē pret dzìvesvietu, kā arī mītnes zemes iedzīvotājiem un jo īpaši - pret tuvākās apkaimes iedzīvotājiem. Piederība vietai, kur respondents šobrīd dz̄ivo mītnes zemē, ir pastiprinājusies $24 \%$ gadījumu, piederība mītnes zemes iedzīvotājiem $-23 \%$, bet piederība tuvākās apkaimes iedzīvotājiem - trešdaliai (33\%) respondentu, kas, iespējams, liecina par veiksmīgu integrēšanos mītnes zemē un tās sabiedrībā.

Kopumā 2019. gada aptaujas dati liecina, ka, salīdzinot ar 2014. gadu, Latvijas emigrantu kopienā nacionālās identitātes dimensija vairs nedominē pār "svešo" un jauno identitāti, proti, ir pieaugusi to respondentu daļa, kas izjūt ciešāku saistību ar mītnes zemi nekā ar Latviju.

Tomēr, jautājot par piederību Latvijai kopumā, netieši tiek norādìts ne tikai uz teritoriālās piederības, bet arī uz citām nacionālās identitātes dimensijām (politisko, kultūras, psihologiisko). Škiet, tieši šie aspekti ietekmē piederības izjūtu atšḳirības salīdzinājumā ar piederību konkrētai vietai Latvijā - cieši saistīti ar Latviju jūtas vairs tikai 59\% emigrējušo (vietai, no kuras izceḷoja, - 70\%). Vienlaikus ar mītnes zemi tikpat ciešu saistību izjūt $61 \%$ aptaujāto. Protams, šie procenti tikai kopumā ilustrē piederības izjūtu hierarhiju emigrantu kopumā, tādēl atgriezīsimies pie piederības apzinias dimensijām un to raksturojuma dažādās emigrantu grupās.

Pamatojoties gan uz klasteranalīzes rezultātu statistiskajiem raksturojumiem (skalu gradācija, klasteru piepildījums), gan interpretācijas apsvērumiem, no vairākiem klasteranalīzes rezultātiem turpmākajai analīzei kā optimāls izvēlēts 4 klasteru variants. Līdzīgs 
1. tabula. Piederība vietai un sociālajām grupām: atbilžu sadalījums 2014. un 2019. gadā un izmaiṇas individuālā līmen̄̄ starp abiem periodiem (\%)

\begin{tabular}{|c|c|c|c|c|}
\hline & 2014 & 2019 & $\begin{array}{l}\text { Piederības izjūta } \\
\text { vājinājusies }\end{array}$ & $\begin{array}{c}\text { Piederības izjūta } \\
\text { pastiprinājusies }\end{array}$ \\
\hline \multicolumn{5}{|l|}{ Saistība ar vietu } \\
\hline .. vietu, kur dzīvoja Latvijā pirms izceḷošanas & 79 & 70 & 14 & 5 \\
\hline .. Latviju kopumā & 68 & 59 & 16 & 9 \\
\hline .. valsti, kurā dzīvo tagad & 57 & 61 & 15 & 15 \\
\hline .. vietu (pilsētu), kur dzīvo tagad & 47 & 60 & 14 & 24 \\
\hline \multicolumn{5}{|l|}{ Piederība sociālajām grupām } \\
\hline .. savas tautības cilvēkiem & 80 & 68 & 22 & 7 \\
\hline .. citiem cilvēkiem no Latvijas ārzemēs & 56 & 55 & 22 & 17 \\
\hline .. Latvijas iedzīvotājiem & 57 & 52 & 21 & 11 \\
\hline $\begin{array}{l}\text {.. tuvākās apkaimes iedzīvotājiem mītnes } \\
\text { zemē }\end{array}$ & 44 & 68 & 12 & 33 \\
\hline .. mītnes zemes iedzīvotājiem & 48 & 63 & 12 & 23 \\
\hline
\end{tabular}

Bāze: 2014. un 2019. gadā atbildējušie respondenti $(n=981)$. No analīzes izslēgti remigranti, proti, tie 2014. gada aptaujas respondenti, kuri šobrīd atgriezušies un dzīvo Latvijā.

rezultāts tika iegūts, balstoties uz 2014. gada emigrantu aptaujas datiem, ${ }^{22}$ kas liecina par diezgan noturīgiem modeliem piederības apzin̄ā, kas raksturīgi vienai vai otrai emigrantu grupai. Klasteru piepildījums atspogul丷ots pielikuma 1. tabulā, bet iegūtās piederības apziņas tipoloǵiskās grupas tiek interpretētas šādi: 1. klasteris - grupa, kuras pārstāvji ir "integrējušies mītnes zemē, cieši piederīgi Latvijai un latviskajam"; 2. klasteris - "piln̄̄bā integrējušies mītnes zemē, atsvešinājušies no Latvijas un latviskā"; 3. klasteris - "vāji integrējušies mītnes zemē, mēreni piederīgi Latvijai un latviskajam"; 4. klasteris - "vāji integrējušies mītnes zemē, cieši piederīgi Latvijai un latviskajam".

Tālāk aplūkosim piederības apziņas tipoloǵiskās grupas, salīdzinot piederības izjūtu intensitāti katrā no tām (sk. 1. attēlu) un sniedzot grupas raksturojumu atbilstoši sociāldemogrāfiskām pazīmēm, atšķirībām emigrantu vērtējumos un dažos rīcības aspektos, noskaidrojot galvenos faktorus, kas ietekmē noteikta piederības izjūtu kompleksa veidošanos.

\footnotetext{
${ }^{22}$ Koroleva 2019.
}

\section{Integrējušies mītnes zemē, cieši piederīgi Latvijai un latviskajam}

Pirmais klasteris jeb emigrantu piederības izjūtu tipologisiskā grupa iekḷauj respondentus, kuri lielā mērā integrējušies pašreizējā mītnes zemē, saglabājot ḷoti ciešu piederību Latvijai un visam latviskajam. Par to liecina izteikta piederības izjūta mītnes zemes un tuvākās apkaimes (pilsētas, kvartāla, ciema, kurā respondents šobrīd dzīvo) iedzīvotājiem, valstij un vietai, kurā viņi šobrīd dzīvo. Atbilžu procentuālais sadalījums parāda to, ka šajā grupā lielākā daḷa respondentu jūtas loti piederīgi mītnes zemes iedzīvotājiem (82\% pret līdzīgi domājošo dal̦u aptaujas izlasē - 63\%) un tuvākās apkaimes iedzìvotājiem (83\% pret kopējo rādītāju izlasē - 68\%) (sk. 1. attēlu). Nozīmīgas atškkirības vērojamas, ja dažādās emigrantu grupās salīdzinām piesaistes ciešumu noteiktai vietai - $61 \%$ jūtas cieši saistîti ar mītnes zemi un $60 \%$ ar vietu (piem., pilsētu, ciemu), kurā vinini šobrīd dzīvo. Acīmredzot veiksmīga integrācija mītnes zemes sabiedrībā nav pretrunā ar spēcīgu nacionālo jūtu saglabāšanos un liecina par transnacionālās identitātes veidošanos, kuru raksturo spēcīga saikne gan ar uzņemošo, gan ar izcelsmes valsti. Uz transnacionālās identitātes dominanci šajā grupā norāda tādu emigrantu lielais īpatsvars, kuri 


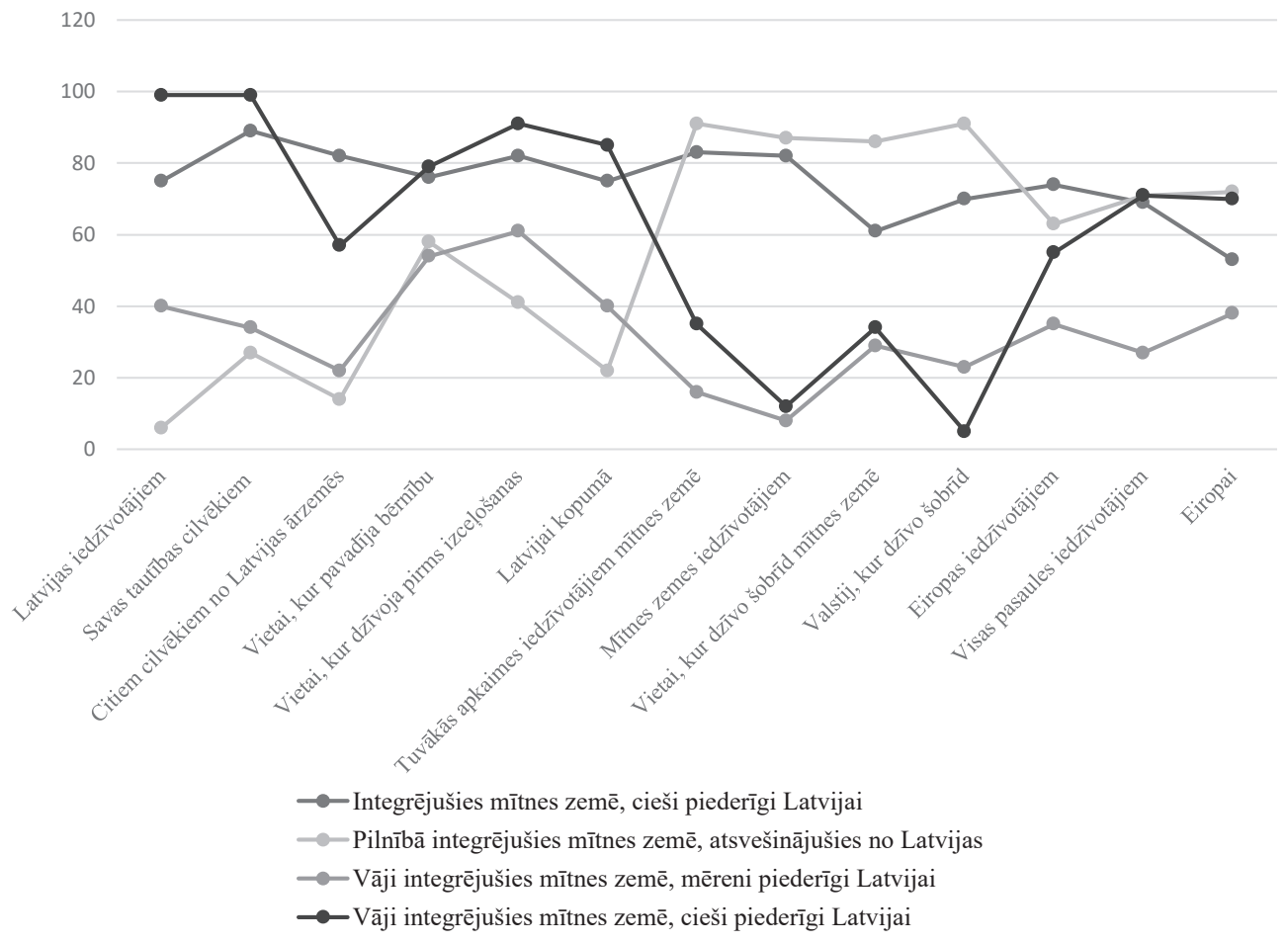

1. attēls. Cieša piederība vietai un kopienai: atbilžu sadalījums klasteros (\%)

Piezīme: aprēḳinā apvienotas atbildes "ḷoti piederīgs" un "piederīgs".

jūtas loti piederīgi un cieši saistîti ar Latviju (75\%), Latvijas iedzīvotājiem (75\%). Salīdzinot ar citām tipolog̣iskajām grupām, vēl stiprāka ir etniskā identitāte $-89 \%$ grupas pārstāvju jūtas piederīgi savas tautīibas cilvēkiem, citiem imigrantiem no Latvijas ( $82 \%$ pret kopējo rādìtāju izlasē - 55\%), kā arī Eiropas un visas pasaules iedzīvotājiem.

Kāds tad ir aplūkotās emigrantu grupas sociāldemogrāfiskais portrets?

Uzreiz jāatzīmē, ka šis ir skaitliski vislielākais klasteris un tajā nozīmīgi pārstāvētas diezgan atšķirīgas emigrantu grupas. Nepārsteidz pirmais atzinums, ka emigrantu vidū, kuri veiksmīgi integrējušies mītnes zemē, saglabājot ciešu saikni un piederību Latvijai, statistiski nozīmīgā līmenī dominē cilvēki, kas visu mūžu vai ilgāku laiku dzīvojuši ārpus Latvijas, proti, pirmo emigrācijas viḷnu pārstāvji, kuri izcelojuši pirms 1991. gada vai uzreiz pēc neatkarības atgūšanas laika posmā no 1991. līdz 2003. gadam. Nozīmīgi mazāk pārstāvēti pēdējos emigrācijas viḷ̣nos (pēc 2011. gada) izbraukušie. Demogrāfiskais raksturojums šajā grupā būtiski neatš̌kiras pēc dzimuma pazīmēm, bet nozīmīgi vairāk nekā pārējos klasteros ir gados vecāku cilvēku (pensijas vecuma respondentu). Atbilstoši emigrācijā pavadītajam laikam dominē cilvēki, kas ārpus Latvijas nodzīvojuši vairāk nekā 15 gadus vai visu mūžu. Šajā tipolog̣iskajā grupā vairāk ir cilvēku ar vidējās izglîtības līmeni (izglîtīibas līmenis tika sadalīts 3 kategorijās). Statistiski nozīmīgā līmenī dominē latvieši, trūkst krievu tautîbas emigrantu. Līdz ar to arī mājsaimniecībā lietotā valoda ir latviešu valoda, īpaši salīdzinot ar grupu, kurā dominē krievu vai cita (t. sk. mītnes zemes) valoda. Pilsonībai nav diferencējoša nozīme, lai gan nozīmīgi mazāk pārstāvēta tāda kategorija kā Latvijas nepilsoni.

Svešumā labāk integrēties noteikti palīdz radi, draugi, kuri jau dzīvojuši mītnes zemē respondenta pārcelšanās laikā (2014. gada 
mērījums). Nepārsteidz, ka saikni ar Latviju veicina šeit palikusī daḷa no paša ǵimenes (dzīvesbiedrs, bērni u. tml.), savukārt ciešāku piesaisti mītnes zemei nodrošina tas, ka mītnes zemē dzīvo draugi no Latvijas. Interesanti, ka šajā klasterī trūkst respondentu, kuriem Latvijā šobrīd palikusi vecāku gimene un kuri mājsaimniecībā dzīvo vieni paši vai kopā ar svešiem cilvēkiem.

Grupā nozīmīgā pārsvarā ir tie, kuri mītnes zemē dzīvo kopā ar savu ǵimeni vai savu vecāku ǵimeni, kas acīmredzot sniedz stabilitātes un miera sajūtu un ḷauj labāk iejusties mītnes zemē, nezaudējot piederību Latvijai. Pēc sociālo tīklu raksturojuma šajā grupā dominē emigranti, kuriem mītnes zemē būtu, kam lūgt palīdzību, ja vajadzētu steidzami aiznemties naudu.

Atbilstoši jau minētajai vecuma tendencei nodarbošanās zin̄ā grupā vērojams nozīmīgs pensionāru, kā arī to respondentu pārsvars, kuru nodarbošanās atbilst kategorijai "cits" (piem., mājsaimnieces).

Pēc materiālās labklājības subjektīvā vērtējuma šajā grupā dominē respondenti no salīdzinoši pārtikušākām ǵimenēm, kuras viegli tiek galā ar ikdienas izdevumiem.

Starp citiem subjektīviem vērtējumiem īpaša nozīme ir apmierinātības (ar dzīvi un atsevišksām dzīves jomām) un uzticēšanās (Latvijas valdībai) līmenim: nozīmīgā pārsvarā ir respondenti, kuri ir pilnībā apmierināti visās dzīves jomās un lielākā mērā nekā citi uzticas Latvijas valdībai.

Nav nozīmīgas atšķirības starp ārvalstīs pastāvīgi dzīvojošajiem un plūstošajiem (likvīdiem) $)^{23}$ migrantiem un tiem, kas dzīvo pārmaiņus Latvijā un ārzemēs, proti, šajā klasterī proporcionāli pārstāvēti kā vieni, tā otri. Līdzdalības mērījums vedina uz domām, ka šis identitātes modelis raksturīgs sociāli aktīvai emigrantu daḷai, jo ḷoti nozīmīgi dominē cilvēki, kuri līdzdarbojas kādā diasporas organizācijā.

${ }^{23}$ Šeit un turpmāk jēdziens "plūstošie (likvīdie) migranti" lietots šaurā izpratnē, definējot šo emigrantu grupu tikai pēc dzīvesvietas pazīmes, proti, tie ir cilvēki, kas dzīvo pārmaiņus Latvijā un ārzemēs.

\section{Pilnūbā integrējušies mītnes zemēe, atsvešinājušies no Latvijas un latviskā}

Otro klasteri jeb tipoloǵisko grupu raksturo l̦oti augsta vai pilnīga integrācijas pakāpe mìtnes zemē un vienlaikus negatīva attieksme pret izcelsmes valsti - Latviju, kā arī pret visām tām pazīmēm, kas kopumā veido nacionālās identitātes dimensijas. Grupā visspēcīgāk izteiktās pazīmes ir piederība mītnes zemes $(87 \%)$ un tuvākās apkaimes iedzīvotājiem (91\%), kā arī vietai (86\%) un valstij (91\%), kurā respondents šobrīd dzīvo. Šai grupai ir atsvešināta attieksme pret visu, kas saistīts ar Latviju un latvisko, kā arī ļoti vāji izteiktas nacionālās identitātes pazīmes. Uz to uzskatāmi norāda piederību raksturojošo atbilžu procentuālais sadalījums. Tikai $6 \%$ jūtas piederīgi Latvijas iedzīvotājiem, 14\% - citiem cilvēkiem no Latvijas ārzemēs. Uz ciešu saistību ar Latviju norādījuši vien $22 \%$ šīs grupas pārstāvju. Hipotētiski tie varētu būt cilvēki, kuri atstājuši Latviju ar rūgtumu sirdī, iespējams, tobrīd izjūtot pat naidīgumu un saglabājot negatīvu attieksmi pret savu izcelsmes valsti, tajā notiekošajiem sociālajiem un politiskajiem procesiem. Visdrīzāk šie cilvēki atstājuši Latviju, ekonomisku apstākḷu spiesti, sociālās neaizsargātības u. tml. iemeslu dēḷ. Šādam spriedumam par labu liecina arī tas, ka, salīdzinot ar iepriekš minētajiem rādītājiem, daudz lielāka daḷa grupas pārstāvju jūtas ciešāk saistīti ar vietu Latvijā, kur pavadīta bērnība (58\%), un dzīvesvietu pirms izcelıšanas (41\%).

Klasteri piepilda jaunāko viḷnu emigranti - izcel̦ojušie laika posmā no 2000. līdz 2003. gadam un ekonomiskās krīzes laika emigranti, kas atstājuši Latviju 2009.-2011. gadā un pēc 2011. gada, trūkst ārpus Latvijas dzimušo un to, kas visu mūžu dzīvojuši ārzemēs vai izceļojuši pirms 1991. gada.

Pēc demogrāfiskajiem rādītājiem dominē jaunāki cilvēki vecumgrupā no 25 līdz 34 gadiem, bet trūkst vecumā 55+, pēc izglītības līmeņa nav būtisku atškirīību. Lielāks ir sieviešu pārsvars, pēc etniskās piederības nedaudz vairāk ir krievu tautības pārstāvju, kā sarunvaloda mājās vairāk norādīta mītnes zemes vai cita valoda.

Līdzīgi kā iepriekšējā grupā, integrāciju mītnes zemē noteikti veicinājis tas, ka 
pārceļoties tur jau sagaidījusi ǵimene vai radinieki, un arī fakts, ka nozīmīgi lielai daḷai mītnes zemē ir tuvi draugi no "vietējiem" vai iebraucējiem (imigrantiem) no citām valstīm. Iespējams, tieši tādēl mītnes zemē šiem cilvēkiem ir, pie kā griezties gan gadījumos, kad slimības dēḷ jāpaliek mājās, gan tad, kad nepieciešams aizņemties naudu vai aprunāties skumju vai nomāktības brīžos. Grupā ievērojami dominē tie, kas mītnes zemē dzīvo kopā ar savu ǵimeni vai arī vienā mājsaimniecībā ar citiem cilvēkiem, kas nav radinieki.

Salīdzinošā mazākumā šajā klasterī ir respondenti, kuriem Latvijā pašlaik dzīvo kāds no paša gimenes un kuriem Latvijā ir kāds īpašums, līdz ar to arī sociālie kontakti ar Latviju ir vājāki.

Pēc nodarbošanās vairāk pārstāvēti gan algotā darbā strādājošie, gan jaunās māmiņas, kas atrodas bērna kopšanas atvalịnājumā, bet trūkst pensionāru. Materiālās labklājīioas jomā vēl nozīmīgāk nekā iepriekšējā klasterī dominē pārtikušas ǵimenes, kuras viegli vai pavisam viegli tiek galā ar ikdienas izdevumiem. Apmierinātības ziṇā šī klastera pārstāvji šobrīd ir loti apmierināti ar visu un būtiski trūkst tādu, kuri ir neapmierināti kādā no dz̄̄ves jomām. N̦emot vērā klastera raksturojumu, nepārsteidz, ka šajā grupā dominē cilvēki, kuri nemaz neuzticas vai l̦oti maz uzticas Latvijas valdībai. Jāsecina, ka šî ir sociāli mazaktīvākā diasporas daḷa, jo grupas pārstāvji neiesaistās nevienas organizācijas darbībā.

Pastāvīgi ārpus Latvijas dzīvojošie nozīmīgi dominē, salīdzinot ar plūstošo migrantu grupu.

\section{Väji integrējušies mītnes zemē, mēreni piederīgi Latvijai un latviskajam}

Trešā klastera respondentus raksturo ḷoti vāja integrācija mītnes zemē, proti, šīs grupas pārstāvji, īpaši salīdzinājumā ar pārējiem respondentiem, jūtas samērā nepiederīgi vai vispār nepiederīgi mītnes zemei un tās iedzīvotājiem, bet tai pašā laikā arī piederība Latvijai ir diezgan vāja (izṇemot vietai Latvijā, no kuras izcelıjuši vai kur dz̄ivojuši bērnībā). Piederības izjūtu tiešie mērījumi liecina, ka no tuvākās apkaimes un mītnes zemes iedzīvotājiem ḷoti piederīgi vai zināmā mērā piederīgi jūtas $16 \%$ un atbilstoši - $8 \%$ grupas pārstāvju, salīdzinoši zemi rādītāji raksturo arī piederību pašreizējai dzīvesvietai - ar mītnes zemi un konkrēto dzīvesvietu cieši saistīti jūtas $29 \%$ un $23 \%$ šis grupas respondentu. Nedaudz spēcīgāka ir šìs grupas latviskā identitāte, par ko liecina ciešāka piederība Latvijas iedzīvotājiem (40\%), savas tautības cilvēkiem (34\%). Latvijai kopumā jūtas piederīgi 40\% š̄̃s grupas pārstāvju. Iespējams, par nostalǵiskām jūtām un ilgām pēc Latvijas liecina tas, ka stiprākas piederības jūtas saista ar vietu, kur pavadīta bērnība, vietu, kur dzīvots pirms emigrācijas (61\%).

Hipotētiski šajā grupā vajadzētu ietilpt jaunāko emigrācijas viḷnu pārstāvjiem, jo integrācijai ir nepieciešams laiks. Empīriskie dati to arī apstiprina: grupā dominē tūlītējie pēckrīzes emigranti (2009.-2011. gadā izbraukušie), respondenti, kuri nodzīvojuši ārpus Latvijas salīdzinoši mazāku laiku - līdz 5 gadiem vai 6-10 gadus. Atšķirībā no citiem klasteriem, nozīmīgi lielāka daḷa šajā grupā ir vīrieši. Pēc vecuma nav izteiktu atšķirību, lai gan nedaudz vairāk pārstāvēta 33-54 gadu vecumgrupa, bet nozīmīgi mazāk jauniešu vecumā līdz 24 gadiem; vairāk krievu tautības respondentu, kas saglabā krievu sarunvalodu mājās.

Izteikti dominē zems (zemākais) izglîtības līmenis. Ieceḷojot mītnes zemēe šos cilvēkus nav sagaidījis nedz kāds ǵimenes loceklis, nedz draugi, arī šobrīd dominē tie, kuri mītnes zemē savā mājsaimniecībā dz̄ivo vieni paši un kuriem ir vāji sociālie sakari (nav cilvēku, kam lūgt palīdzību saslimšanas gadījumā vai ja steidzami jāaizṇemas nauda). Nozīmīgā pārsvarā ir cilvēki, kuriem Latvijā palicis kāds vecāku ǵimenes loceklis, draugi, kas, iespējams, arī izskaidro ciešākas piederības jūtas vietai, no kuras izcelıtots, savukārt nozīmīgi trūkst to, kas jau ieguvuši draugus mītnes zemē.

Pēc nodarbošanās - vairāk algotā darbā nodarbinātie, trūkst studējošo un nestrādājošo. Atšķirībā no divām iepriekšējām grupām, šajā klasterī vairāk pārstāvēti cilvēki no salīdzinoši trūcīgākām ǵimenēm, kuri pēc subjektīvā vērtējuma ikdienas izdevumus var segt tikai ar grūtībām vai pat lielām grūtībām.

Apmierinātības līmenis neietekmē piederību šim klasterim, bet uzticēšanās līmenis Latvijas valdībai ir ārkārtīgi zems. Līdzdalības 
aspektā izteikti pasīva grupa, kurā dominē cilvēki, kas nepiedalās nevienas organizācijas nedz latviešu diasporas, nedz vietējo organizāciju - aktivitātēs.

\section{Väji integrējušies mītnes zemē, cieši piederīgi Latvijai un latviskajam}

Pēdējā - ceturtā - klastera pārstāvjus, līdzīgi kā iepriekšējo tipoloǵisko grupu, raksturo salīdzinoši vāja piederība mītnes zemei un tās iedzīvotājiem. Tas liecina par ne pārāk veiksmīgu integrēšanos mītnes zemē, bet vienlaikus šìs grupas pārstāvjiem ir spēcīga nacionālās identitātes apziņa - l̦oti cieša piederības izjūta Latvijas valstij un visam latviskajam. Šajā ziņā izjūtu dimensija līdzinās pirmā klastera pārstāvju identitātes raksturojumam, tikai piederības izjūtas raksturo vēl augstāka intensitāte attiecībā uz izcelsmes valsti: 99\% jūtas loti piederīgi un zināmā mērā piederīgi Latvijas iedzīvotājiem, savas tautības cilvēkiem, $57 \%$ - citiem cilvēkiem no Latvijas ārzemēs. Salīdzinot ar citām grupām, jānorāda uz īpaši spēcīgu emocionālo saikni ar Latviju, par ko liecina tas, ka absolūtais vairākums grupas pārstāvju jūtas ļoti cieši saistīti ar Latviju (85\%), vēl vairāk - ar vietu Latvijāa , no kuras izceḷoja (91\%).

Nozīmīgi vājāka ir šīs grupas saikne ar dzīvesvietu mîtnes zemē (34\%) un tuvākās apkaimes iedzīvotājiem (16\%) un jo īpaši ar mìtnes zemes iedzīvotājiem (12\%) un mītnes zemi kopumā $(6 \%)$.

Atkarībā no emigrācijas viḷniem šajā grupā nav vērojamas nozīmīgas atškirīibas, izṇemot vienīgi to, ka vairāk ir 2004.-2008. gadā izcelojušo. Dominē gados jauni cilvēki: visjaunākās vecumgrupas (15-24 gadi) pārstāvji, kā arī 35-54 gadus veci cilvēki. Nozīmīgi pārstāvēti tie, kas pārmaiņus dzīvo Latvijā un ārvalstīs, bet ārpus Latvijas kopumā dzīvojuši 5-10 gadus.

Pēc izglîtības dominē emigranti ar augstāko izglîtības līmeni, latvieši. Līdzīgi kā iepriekšējā grupā, vairāk ir tādu cilvēku, kuriem kāds no gimenes locekḷiem joprojām dzīvo Latvijā, kur ir arī nekustamais īpašums. Dominē tie, kas mītnes zemē mājsaimniecībā dzīvo vieni paši, bet atbilstoši trūkst respondentu, kuri mītnes zemē dzīvo kopā ar savu vai vecāku ǵimeni. Sociālie sakari mītnes zemē salīdzinoši vāji (pārsvarā nav, kam lūgt palīdzību, ja steidzami vajadzētu aizṇemties naudu, un nav, ar ko aprunāties skumju, nomāktības brīžos).

Pēc nodarbošanās tie pārsvarā ir jauni cilvēki, kuri studē, mācās ārzemēs, pašnodarbinātie un uzņēmēji, kā arī nestrādājošo grupa. Pēc pārticības līmeña dominē cilvēki no materiāli mazāk nodrošinātām gímenēm, kuriem ar grūtībām vai pat ḷoti lielām grūtībām izdodas norēḳināties par ikdienas izdevumiem. Nozīmīgi vairāk ir tādu, kas kādā no dzīves sfērām ir neapmierināti (īpaši cilvēki, kas nav apmierināti ar gimenes dzīvi), bet trūkst tādu, kas ir apmierināti ar visu.

Salīdzinoši liels šajā grupā ir tādu cilvēku īpatsvars, kurus raksturo vidēji augsts uzticēšanās līmenis.

Tāds kopumā ir piederības apziņas tipologisko grupu portrets, bet, pirms izdarìt secinājumus par piederības izjūtu ietekmējošiem faktoriem, tiks aplūkots, kādas pazīmes ietekmē raksta sākumā identificētās izmaiṇas piederības izjūtās.

\section{Piederības jūtu izmaiṇas ietekmējošie faktori}

Lai novērtētu minētos faktorus, tika aprēḳināti trīs logisistiskās regresijas modeḷi, kā atkarīgos main̄̄gos iekḷaujot šādas izmaiņu kategorijas: (1) vājinājusies piederības izjūta Latvijai un latviskajam, (2) pastiprinājusies piederības izjūta Latvijai un latviskajam, (3) pastiprinājusies piederības izjūta mītnes zemei un tās iedzīvotajiem (sk. pielikuma 2. tabulu). Tālāk aplūkoti regresiju rezultāti atsevišḳi pa main̄̄go grupām, atgādinot, ka runa ir tikai par piederības izjūtu pastiprināšanos vai vājināšanos pēdējo piecu gadu laikā.

\section{Emigrācijas pieredze: emigrācijas laiks un iemesli}

Atbilstoši hipotēzei izceḷošanas un svešumā pavadītajam laikam ir būtiska ietekme uz indivīda piederības izjūtas veidošanos un iespējamām identitātes transformācijām: jo ilgāks laiks pavadīts ārpus izcelsmes valsts, jo lielāka varbūtība, ka indivīds būs veiksmīgāk 
adaptējies un integrējies mītnes zemē, veidojoties ciešākai piederībai gan mītnes valstij, gan lokālai videi - dzīvesvietai un apkaimes iedz̄̄votājiem. Tomēr svešumā pavadītajam laikam nav viennozīmīga un lineāra ietekme uz piederību Latvijai un latviskajam. Skaidrojošāka pazīme šajā ziṇā ir emigrācijas vilnis. Kopš 2014. gada piederības jūtas Latvijai un latviskajam nozīmīgi mazinājušās ekonomiskās krīzes un pēckrīzes laikā (2009-2011) izcelıjušo grupā. Jau pirmās aptaujas dati liecināja, ka tieši šai grupai kopumā bija diezgan negatīva attieksme pret Latviju un latvisko. Iespējams, to var skaidrot ar ekonomiskajiem apstākḷiem un iemesliem, kāpēc cilvēki atstājuši vai bija spiesti atstāt dzimto zemi, daudzos gadījumos arī gimeni. Citos periodos emigrējušo grupās salīdzinoši ir mazāka varbūtība, ka piederības izjūta latviskajam būs mazinājusies. Savukārt 90. gadu emigrantu vidū un pirmskrīzes laikā (2004-2008), kad emigrācijas iemeslu vidū nedominēja ekonomiskie apstākḷi un vilšanās, ir lielāka varbūtība, ka pēdējo piecu gadu laikā piederības izjūtas Latvijai un latviskajam ir pieaugušas. Piederība mītnes zemei salīdzinājumā ar citiem viḷniem pastiprinājusies 2004.-2008. gadā izceḷojušo grupā.

\section{Demogrāfiskie faktori un izglītība}

Dzimuma pazīme statistiski nozīmīga bija tikai vienā modelī, un interesanti, ka tieši vīriešu vidū pastiprinās piederība Latvijai.

Diezgan nozīmīga ietekme piederības apziṇas izmain̄ās ir izglītībai. Neanalizējot konkrētu izglîtīibas veidu, pastāv lielāka varbūtība, ka augstāk izglītoto respondentu grupā būs pastiprinājušās gan piederības izjūtas Latvijai un latviskajam, gan mītnes zemei. Savukārt ir lielāka varbūtība, ka emigranti ar zemāku izglītības līmeni ir gan sliktāk integrējušies mītnes zemē, gan vienlaikus mazinājusies to piederība Latvijai.

Citu piederības apziṇu ietekmējošo faktoru kontekstā arī vecumam ir statistiski nozīmīga loma. Attiecībā pret vecāko respondentu grupu (55+) visās jaunākajās grupās mazinājusies piederības izjūta Latvijai - jo īpaši vecumā no 35 līdz 54 gadiem. Šai vecumgrupai gan raksturīgas visnozīmīgākās kolīzijas piederības izjūtās, jo daḷai respondentu savukārt pastiprinājusies piederības izjūta Latvijai.
Piederība mītnes zemei un tās iedzīvotājiem kopumā pastiprinās, samazinoties respondentu vecumam, proti, jauni cilvēki ātrāk adaptējas un iedzīvojas mītnes zemē.

Tautībai un mājās lietotajai valodai ir statistiski nozīmīga ietekme visos modeļos. Interesanti, ka attiecībā pret citu tautîbu emigrantiem (izṇemot krievu tautîbu) latviešiem ir lielāka varbūtība nokḷūt grupā, kurā mazinās piederība Latvijai un tai pašā laikā pastiprinās piederība mītnes zemei. Savukārt piederība Latvijai salīdzinoši pieaugusi cittautībnieku vidū.

Nacionālās piederības jūtu saglabāšanā un stiprināšanā vēl lielāka nozīme ir ǵimenē lietotajai sarunvalodai. Analīzes rezultāti norāda uz to, ka, salīdzinot ar gímenēm, kurās sarunvaloda ir latviešu valoda, vairāk atsvešinās ǵimenes, kurās tiek lietota krievu valoda. Latvijas pilsonībai nav īpaši diferencējoša loma, vienīgi mītnes zemes pilsonības iegūšana mazina varbūtību, ka mainīsies piederības jūtas pret Latviju.

\section{Gimene, sociālie tīkli un lìdzdalība}

Piederības jūtu intensitātes diferenciācijā būtiskākā nozīme ir ǵimenes "sadalīšanas" faktoram. Nacionālās piederības saišu stiprumu ietekmē Latvijā palikusī ǵimenes daḷa (gan paša respondenta ǵimene, gan vecāku ǵimenes), tuvi draugi, kā arī materiālais komponents - īpašums Latvijā, kas palielina varbūtību, ka cilvēka piederība Latvijai būs ne tikai spēcīga, bet pat pastiprināsies. Piederību latviskajam palīdz saglabāt arī tas, ka mītnes zemē dzīvo draugi no Latvijas.

Pretrunīgāk tas ietekmē tieši izmainas piederības apziņā. Lielāka ir varbūtība, ka tiem, kam Latvijā palikuši vecāki vai tuvi radinieki, piederības izjūtas Latvijai ir stipras un arī pieaugušas, bet tikpat lielai daḷai šīs jūtas ir arī mazinājušās. Līdzīga ietekme vērojama gadījumos, ja Latvijā dzīvo respondenta paša ǵimene (dzīvesbiedrs, bērni): daḷai respondentu nozīmīgi pastiprinās piederības jūtas Latvijai, daḷai - mītnes zemei. Ja respondents dzīvo ārzemēs kopā ar savu gimeni vai viens pats, tas neveicina piederības jūtu pastiprināšanos pret mîtnes zemi. Savukārt ir lielāka varbūtība, ka sociālo kontaktu paplašināšanās, jauni 
draugi sekmē piederības izjūtu mītnes zemei pastiprināšanos.

Līdzdalība diasporas organizācijās sekmē piederības jūtu Latvijai saglabāšanu un noz̄̄mīgi mazina atsvešināšanās varbūtību.

\section{Citu pazīmju ietekme uz piederības izjūtu rādītāju izmainām}

Materiālā pārticība būtiski ietekmē tikai piederības izjūtu izmainas attiecībā pret Latviju. Tās vienlīdz nozīmīgi mazinās gan tiem, kas pieder pie materiāli nodrošinātākajām grupām, gan tiem, kas ar lielām grūtībām var savilkt galus.

Nodarbinātība ir svarīgs faktors, kas ietekmē integrāciju mītnes zemē. Darbs, uzṇēmējdarbība, kā arī atrašanās bērna kopšanas atvalinājumā prognozē labāku integrēšanos mītnes zemē. Tāpat cita nodarbošanās (piem., mājsaimnieces, kuras apprecējušās un dzīvo vīra paspārnē) gandrīz par trešdalı palielina iespēju, ka pieaugs arī piederības jūtas mītnes zemei.

Augstāka apmierinātības pakāpe saistīta ar piederības izjūtu mìtnes zemei pieaugumu, vienlaikus vājinoties piederības izjūtām Latvijai.

Interesanti, ka tieši plūstošo migrantu grupā, kuri pārmainus dzīvo Latvijā un ārzemēs, vērojamas vismazākās izmainas piederības apziṇā - nevājinās piederības jūtas Latvijai, bet arī piederība mītnes zemei nepastiprinās.

Pirms izdarīt gala secinājumus, aplūkosim vēl pēdējo jautājumu, kas cieši saistīts ar piederības jūtu izcelsmes zemei saglabāšanu, kā arī jaunu piederības jūtu veidošanos mītnes zemē.

\section{Piederība un atgriešanās plāni}

Longitudinālā pieeja, kas ḷauj novērtēt izmaiṇas individuālā līmen̄̄, sniedz arī unikālu iespēju novērot, kā realizējas cilvēku plāni. Šai gadījumā - kā pēc pieciem gadiem ir piepildījušies vai mainījušies atgriešanās plāni.

Dati liecina, ka kopš 2014. gada no šīs emigrantu kopas Latvijā uz dzīvi atgriezušies 9\% (atbilstoši 2019. gada aptaujā sniegtajām atbildēm), ārzemēs un Latvijā pārmainusus dzīvo $12 \%$, bet pastāvīgi ārpus Latvijas turpina dzīvot 79\% respondentu. Abos aptaujas posmos respondentiem tika jautāts par atgriešanos tuvāko sešu mēnešu, piecu gadu laikā vai vecumdienās, atbilžu skalā iekḷaujot arī kategoriju "varbūt, atkarībā no apstākḷiem". Uzskatāmības nolūkā aprēḳināti jauni kumulatīvi mainīgie, veidojot šãdas viennozīmīgas kategorijas neatkarīgi no laika posma: 1) jā, plāno atgriezties; 2) varbūt, atkarībā no apstākḷiem un 3) nē, neplāno atgriezties. 2. attēls atspoguḷo, kā sadalās cilvēku plūsmas atkarībā no plāniem 2014. gadā: tobrīd Latvijā plānoja atgriezties gandrīz trešdaļa (31\%) respondentu, $26 \%$ bija stingri nolēmuši neatgriezties, bet salīdzinoši lielākā daḷa (43\%) piẹ̦āva iespēju atgriezties atkarībā no dažādiem apstākḷiem. 2019. gada dati liecina, ka kopumā procentuāli pieaugusi to respondentu grupa, kas neplāno atgriezties (no 26\% līdz 33\%). Salīdzinoši mazākas fluktuācijas vērojamas grupā, kas jau pirms pieciem gadiem bija pieņēmusi lēmumu neatgriezties Latvijā - no $26 \%$ respondentu, kas toreiz bija nolēmuši neatgriezties, šobrīd neplāno atgriezties $17 \%$, iespēju, ka atgriezīsies noteiktos apstākḷos, pielıauj $7 \%$, bet $2 \%$ nolēmuši atgriezties un $0,2 \%$ atgriezušies.

Daudzveidīgākas ir to emigrantu trajektorijas, kuri pirms pieciem gadiem plānoja atgriezties. Šo respondentu plūsma sadalās mazāk vienmērīgi - 5\% no tiem ir jau atgriezušies Latvijāa, $8 \%$ ir nolēmuši to darīt, bet salīdzinoši liela grupa ieplūst nenoteiktības kategorijā - atkarībā no apstākliiem (13\%), aptuveni $1 \%$ vairs neplāno atgriešanos.

Atbilstoši prognozei visvairāk sazarojas to respondentu grupa, kuri bija piel̦āvuši iespēju atgriezties atkarībā no apstākḷiem: no šīs grupas $(43 \%)$ neliela daḷa (3\%) respondentu tomēr atgriezušies Latvijāa, lielākā daḷa (19\%) pieņems lēmumu atkarībā no apstākḷiem, bet salīdzinoši liela daḷa (11\%) šobrīd jau nolēmuši neatgriezties. Pozitīvi, ka daḷa (9\%) tomēr mainījusi savu viedokli un domā par atgriešanos.

Šì raksta kontekstā svarīgi aplūkot, kā atgriešanās plāni saistīti ar piederības apziņu, jo jau 2014. gada dati liecināja, ka pastāv nozīmīga korelācija starp šīm pazīmēm. Šo pašu saistību l,oti pārliecinoši apliecina arī 2019. gada dati. Respondentu daḷa, kuri plāno atgriezties Latvijā, ir nozīmīgi augstāka to emigrantu klasterī (4.), kam spēcīgi izteiktas nacionālās piederības jūtas Latvijai un visam 


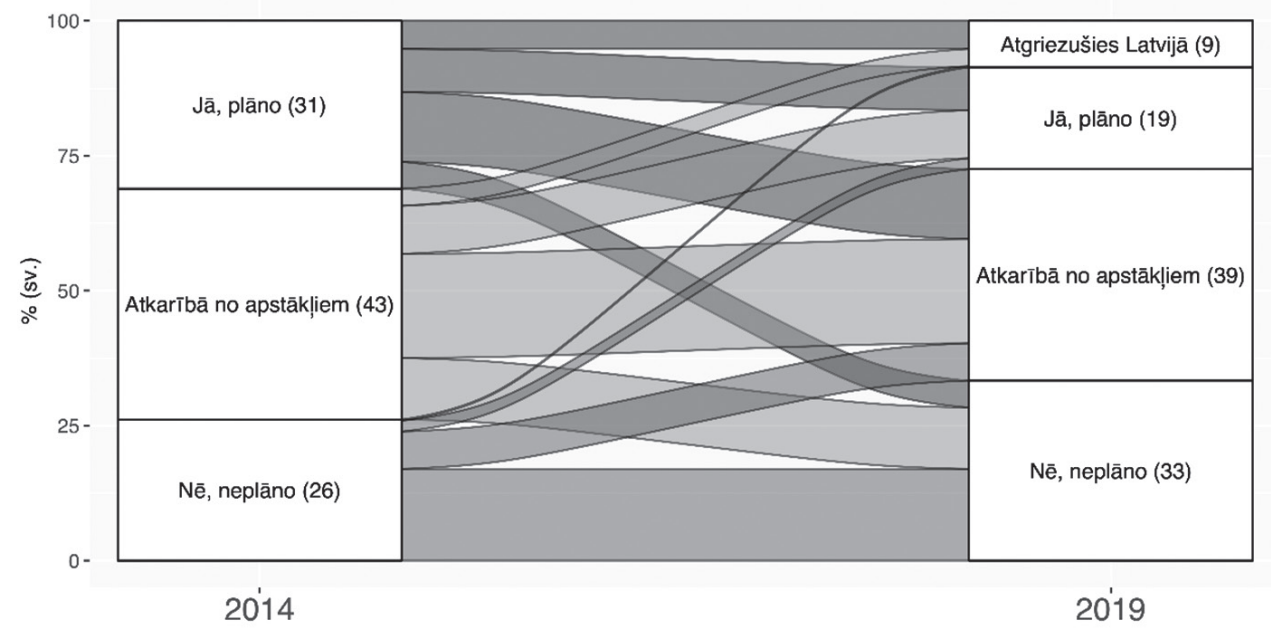

2. attēls. Respondentu atgriešanās Latvijā plāni 2014. un 2019. gadā (\%)

Piezīme: konsolidētās atbildes par plāniem sešu mēnešu, piecu gadu laikā un vecumdienās. Bāze: $n=1073$. A. Aleksandrova vizualizācija.

2. tabula. Atgriešanās plāni atkarībā no piederības apziṇas dimensijām (\%)

\begin{tabular}{|l|c|c|c|c|c|}
\hline \multicolumn{1}{|c|}{ Piederības dimensijas } & 1. klasteris & 2. klasteris & 3. klasteris & 4. klasteris & SigX $^{\mathbf{2}}$ \\
\hline Plāno atgriezties Latvijā & 22 & 2 & 17 & 49 & $<0,001$ \\
\hline $\begin{array}{l}\text { Plāno atgriezties atkarībā } \\
\text { no apstākḷiem }\end{array}$ & 50 & 41 & 40 & 34 & $<0,001$ \\
\hline Neplāno atgriezties Latvijā & 28 & 57 & 43 & 17 & $<0,001$ \\
\hline
\end{tabular}

latviskajam. Šajā grupā gandrīz puse $(49 \%)$ plāno atgriezties Latvijāa kamēr grupā, kuru raksturo atsvešināšanās no Latvijas, to plāno darīt tikai $2 \%$ respondentu, bet vairāk nekā puse $(57 \%)$ nedomā par atgriešanos Latvijā. Interesanti sadalās šì brīža plāni 1. klasterī, kuru nosacīiti varam dēvēt par transnacionālās identitātes grupu (vienlīdz cieši piederīgi kā Latvijai, tā mītnes zemei): puse (50\%) šîs grupas pārstāvju pieḷauj domu par atgriešanos noteiktos apstākḷıs, pārējie dalās salīdzinoši līdzīgās dalāās: plāno atgriezties $22 \%$ un nedaudz lielāka daḷa (28\%) neplāno to darīt.

\section{Kopsavilkums un secinājumi}

Emigrantu analīze, kas balstīta uz kvantitatīivās aptaujas empīirskajiem datiem, liecina, ka piederības izjūtas atkarībā no to intensitātes un objekta iespējams sagrupēt noteiktos piederības klasteros, kas norāda uz atšḳiir̄̄ām piederības apzinnas dimensijām dažādās emigrantu grupās. Katras klastergrupas raksturojums, kas sniegts šajā rakstā, uzskatāmi demonstrē galvenās pazīmes, kas ietekmē subjektīvās piesaistes Latvijai saglabāšanos vai vājināšanos, kā arī piederības jūtu un jaunu identitāšu veidošanos uzṇēmējvalstī. Regresijas analīzes rezultāti savukārt pirmo reizi ḷauj identificēt faktorus, kas ietekmē piederības izjūtu izmaiņas individuālā līmenī.

Kopumā analīzes rezultāti apstiprina hipotēzes, norādot uz analīzē iekḷauto faktoru nozīmīgu saistîbu ar piederības jūtu veidošanos un izmaināam to intensitātē emigrācijā. Daḷeji apstiprinās hipotēzes par dzimuma, pilsonības ietekmi (ierobežota nozīme tikai kādā no modeliem).

Svarīga nozīme piederības izjūtu transformācijās emigrācijā ir laika faktoram. Turklāt 
laikam šajā gadījumā ir divējāda nozīme - gan ārpus dzimtenes nodzīvotie mēneši, gadi, gan izceḷošanas periods - emigrācijas vilnis, kas saistîts arī ar izcelıošanas iemesliem un emocionālo fonu, kādā cilvēks atstājis Latviju.

Piederības izjūtu diferenciācijā būtiska nozīme ir ǵimenei un sociālajām saitēm, proti, vai cilvēks svešumā dzīvo viens vai kopā ar ǵimeni, draugiem.

Spēcīgu nacionālās piederības jūtu saglabāšanos un pastiprināšanos laika gaitā (sk. 3 . un 4. klasteri) neatkarīgi no integrācijas un piederības mītnes zemei ietekmē Latvijā palikusī gimenes daḷa un sociālo kontaktu plašums Latvijā. Vispirms jau tie ir respondenta ǵimenes locekḷi vai vecāku gímenes locekḷi, kā arī tuvi draugi Latvijāa, kas liek izjust ciešāku piederību, piem., vietai, no kuras izceḷjis. Materiālais komponents, kas stiprina piederības jūtas, - īpašums Latvijā. Savukārt atškirtība no tuviniekiem, kas ir cēlonis neapmierinātībai ǵimenes dz̄̄vēe kā arī neapmierinātība ar darbu un dzīvi kopumā ir nozīmīgi riska faktori, kas traucē justies piederīgiem jaunajai dzīvesvietai (šo grupu raksturo vāja piederības izjūta mītnes zemei, dzīvesvietas apkārtnei un mītnes zemes iedzīvotājiem).

Tautībai ir statistiski nozīmīga ietekme uz izmaiṇām piederības izjūtās visos modeḷos, bet vēl lielāka nozīme, īpaši nacionālās piederības jūtu saglabāšanā un stiprināšanā, ir ǵimenē lietotajai sarunvalodai (šajā gadījumā latviešu valodai).

Piederības jūtu transformācijas nozīmīgi ietekmē respondenta vecums. Gados jaunāki cilvēki kopumā ātrāk adaptējas un iedzīvojas mītnes zemēe, bet vienlaikus ātrāk aizmirst par savu izcelsmi. Piederība mītnes zemei un tās iedzīvotājiem pastiprinās, bet piederība Latvijai vājinās, samazinoties respondentu vecumam.

Subjektīvo pazīmju loks, kas ietekmē piederības formu dažādību, ir apmierinātība ar dažādām dzīves jomām un uzticēšanās līmenis politiskajām institūcijām (otrajā viln̄̄ iekļauta tikai uzticēšanās Latvijas valdībai). Augstāks apmierinātības līmenis liecina gan par labvēlīgiem sociālekonomiskajiem apstākḷiem, gan sakārtotību personiskajā dzīvē un stiprina piederības apziņu kā izcelsmes, tā arī mītnes zemei. Tas pats sakāms par uzticēšanos - augstāks uzticēšanās līmenis (šajā gadījumā valdībai Latvijā) saistīts ar ciešāku piederības jūtu veidošanos Latvijai, bet līdzdalība diasporas organizācijās kalpo nacionālās identitātes jūtu uzturēšanai.

Par vēlmi norobežoties vai konfrontēties ar izcelsmes valsti un visu tajā notiekošo liecina l,oti vājas nacionālās piederības jūtas (2. klasteris). Šāas izjūtas biežāk raksturo emigrantus, no kuriem lielākā daḷa izceḷojusi ekonomiskās krīzes un pēckrīzes laikā, iespējams, nereti atstājot valsti ar rūgtumu sird̄̄. Galvenais izcel̦ošanas iemesls - vēlme uzlabot dzīves kvalitāti (2014. gada mērījumi). Vājas saiknes uzturēšana ar izcelsmes valsti ir vai nu indivīda brīva izvēle, vai, iespējams, objektīvi nosacīta, jo dalai šo emigrantu nav palicis, ar ko uzturēt šīs saites (nav tuvu draugu nedz Latvijā, nedz izceḷotāju no Latvijas vidū), toties veidojas draudzības saites ar vietējiem. Nav īpašumu Latvijā. To emigrantu grupā, kuri nejūtas piederīgi Latvijai vai kuriem mazinājusies piederības izjūta Latvijai, vairāk pārstāvēti cilvēki ar salīdzinoši zemu izglītības līmeni, politisko uzskatu ziņā prevalē īpaši zems uzticēšanās līmenis Latvijas valdībai. Tomēr, kā liecina pētījuma dati, piederības izcelsmes valstij mazināšanās automātiski nepastiprina piederības jūtas un jaunas identitātes veidošanos mītnes zemē.

Transnacionālā identitāte ir viena no piederības formām un ietver gan ciešu piederību mītnes zemei, tās iedzīvotājiem, gan izcelsmes valstij. Tās veidošanās pamatā ir atvērtība transnacionālām attiecībām. Kā liecina abu aptauju dati, šādu ambivalentu piederības jūtu veidošanos un pastiprināšanos nozīmīgā pakāpē prognozē iespēja dzīvot kopā ar savu ǵimeni $^{24}$, augstāks respondenta izglītības līmenis, materiālā pārticība un augstāks apmierinātības līmenis visās dzīves jomās.

Transnacionālās identitātes veidošanos traucē tādi faktori kā nespēja atrast darbu, finansiālas grūtības utt., kas ir ekonomiskie izceļošanas iemesli un cieši korelē ar emigrācijas vilni, kā arī nepatika pret politiskajām

${ }^{24}$ 2014. gada aptaujas dati l̦auj secināt, ka nokḷušsanu šajā klasifikācijas grupā ietekmē arī laulības ar ārzemnieku un aizbraukšana, lai pievienotos gimenei. 
norisēm Latvijā, neuzticēšanās. Kā jau sacīts, apmierinātība ar dzīvi kopumā, augstāks uzticēšanās līmenis veicina pozitīvu piederību kā mītnes zemei, tā arī izcelsmes valstij, turpretim neapmierinātība ar kādu no dzīves aspektiem - darbu, ǵimenes dzīvi, sociālekonomiskajiem apstākḷiem - ietekmē atsvešināšanos, (ne)piederību.

Runājot par nākotni, jau tagad ir skaidrs, ka lielākā daļa no tiem, kas izbraukuši pēdējo emigrācijas viḷnu laikāa, Latvijā neatgriezīsies. Cilvēki meklē un atrod jaunus piederības avotus mītnes zemē, iesakṇojas citā valstī. Turklāt, kā liecina mūsu pētījuma dati, lielākā daḷa emigrējušo ir apmierināti un kḷūst aizvien apmierinātāki ar dzīvi. Tomēr mūsdienās, kad ir kḷuvis daudz vienkāršāk ne tikai mainīt dzīvesvietu, bet arī uzturēt kontaktus ar izcelsmes valsti, strādāt vai mācīties attālināti, varbūt var cerēt, ka daļai no Latvijas aizbraukušo piederības izjūta savai zemei, dzimtajai vietai, savai tautai izkonkurēs jaunās piederības jūtas mītnes zemei, tās kopienai. Un, kā liecina pētījuma rezultāti, varbūtība, ka cilvēks neplāno vairs atgriezties Latvijā vai pielıauj iespēju atgriezties kaut kad vecumdienās, ir nozīmīgi augstāka to emigrantu grupā, kas atsvešinājušies no latviskā un nejūtas piederīgi Latvijai, un pretēji nozīmīgi samazināta to emigrantu vidū, kuriem nacionālās identitātes apziņa ir spēcīga.

\section{VĒRES}

Baffoe, M. (2011) Navigating Two Worlds: New Identity Constructions as Determinants for Successful Integration of New Black Immigrant and Refugee Youth in Canadian Society. Journal of Social Sciences, 7, 4, 475-484. Pieejams: https://doi.org/10.3844/jssp.2011.475.484 (09.09.2020.).

Bela, B.; Zepa, B. (red.) (2013) Identitātes. Kopienas. Diskursi. Rīga : LU Akadēmiskais apgāds.

Bela, B. (2014) Starptautiskā migrācija un nacionālā identitāte - transnacionālās piederības veidošanās. Rozenvalds, J.; Zobena, A. (red.) Daudzveid̄̄gās un mainīgās Latvijas identitātes. Rīga : LU Akadēmiskais apgāds, 294-315.

Bokser-Liwerant, J. (2002) Globalization and Collective Identities. Social Compass, 49, 2, 253-271, doi: $10.1177 / 0037768602049002009$

De Certeau, M. (1984) The Practice of Everyday Life. Berkeley, CA : University of California Press.

Frideres, J. S. (2002) Immigrants, Integration and the Intersection of Identities. Pieejams: canada.metropolis. net/events/diversity/immigration.pdf (09.09.2020.).

Goldmanis, M. (2015). Statistisko svaru dizains pētījumā "Latvijas emigrantu kopienas”. Mieriņa, I. (red.) Latvijas emigrantu kopienas: cerību diaspora. Rīga : LU Filozofijas un socioloǵijas institūts.

Grant, P. R. (2007) Sustaining a Strong Cultural and National Identity: The Acculturation of Immigrants and Second-generation Canadians of Asian and African Descent. Journal of International Migration and Integration 8, 89. Pieejams: https://doi.org/10.1007/s12134-007-0003-2 (09.09.2020.).

Hall, S. (1996) Introduction: Who needs “identity"? Hall, S.; du Gay, P. (eds.) Questions of Cultural Identity. London: Sage, 1-17.

Hazans, M. (2011) Latvijas emigrācijas mainīgā seja: 2000-2010. Zepa, B.; Kḷave, E. (red.) Latvija. Pārskats par tautas attīstību 2010./2011: Nacionālā identitāte, mobilitāte un rīcībspēja. Rīga : LU Akadēmiskais apgāds, 70-91.

Hedetoft, U. (2004) Discourses and Images of Belonging: Migrants Between New Racism, Liberal Nationalism and Globalization. Christiansen, F.; Hedetoft, U. (eds.) The Politics of Multiple Belonging. ethnicity and nationalism in Europe and East Asia. England : Ashgate Publishing, 24-45.

Hornsey, J. M.; Jetten, J. (2004) The Individual Within the Group: Balancing the Need to Belong With the Need to Be Different. Personality and Social Psychology Review, 8, 3, 248-264.

Koroleva, I. (2019) The Complex Identities of Latvians Abroad: What Shapes Migrants' Sense of Belonging? Kasa, R.; Mierina, I. (eds.) The Emigrant Communities of Latvia. National Identity, Transnational Beloning, and Diaspora Politics. Cham : Springer.

Koroḷeva, I.; Rungule, R. (2013) Latvijas jauniešu sociāli teritoriālā piederība: etniskā un nacionālā identitāte. Bela, B.; Zepa, B. (zin. red.) Identitātes. Kopienas. Diskursi. Rīga: LU Akadēmiskais apgāds, $27-47$. 
Krzyżanowski, M.; Wodak, R. (2008) Multiple Identities, Migration and Belonging: 'Voices of Migrants'. Caldas-Coulthard, C. R.; Iedema, R. (eds.) Identity Trouble. London : Palgrave Macmillan. Pieejams: https://doi.org/10.1057/9780230593329_6(09.09.2020.).

Ķešāne, I. (2011) Emigrācija un identitāte. Zepa, B.; Kḷave, E. (red.) Latvija. Pārskats par tautas attīstību 2010/2011. Nacionālā identitāte, mobilitāte un rīcìbspēja. Rīga : LU Akadēmiskais apgāds, 64-70.

Lulle, A. (2011) Home redefined: Latvians in Guernsey. Garda-Rozenberga, I.; Zirnite, M. (eds.) Oral History: Migration and Local Identities. Riga : LU Filozofijas un sociologijas institūts, 23-33.

May, V. (2011) Self, Belonging and Social Change. Sociology, 45, 3, 363-378.

Rashid, T. (2007) Configuration of National Identity and Citizenship in Australia: Migration, Ethnicity and Religious Minorities, Alternatives, 6, 2-3, Fall \& Winter, 1-27. Pieejams: https://ssrn.com/abstract $=2044237$ (09.09.2020.).

Rummens, J. (2001) Canadian Identities: An Interdisciplinary Overview of Canadian Research on Identity. Pieejams: canada.metropolis.net/events/ethnocultural/publications/identity_e.pdf (09.09.2020.).

Rungule, R.; Koroḷeva, I. (2014) Latvijas jauniešu daudzveidīgās identitātes. Rozenvalds, J.; Zobena, A. (red.) Daudzveidīgās un main̄̄gās Latvijas identitātes. Rìga : LU Akadēmiskais apgāds, 251-270.

Sime, D. (2018) Belonging and Ontological Security Among Eastern European Migrant Parents and Their Children. Central and Eastern European Migration Review, 7, 1, 35-53.

Skrbiš, Z. (2008) Transnational Families: Theorising Migration,Emotions and Belonging. Journal of Intercultural Studies, 29, 3, 231-246, doi:10.1080/07256860802169188.

Zepa, B.; Kḷave, E. (red.) (2011) Latvija. Pārskats par tautas attīstību 2010/2011. Nacionālā identitāte, mobilitāte un rīcībspēja. Rìga : LU Sociālo un politisko pētìjumu institūts.

\section{Pielikums}

1. tabula. Piederības apziņas dimensijas: respondentu sadalījums klasteros

\begin{tabular}{|l|c|c|}
\hline & \multicolumn{2}{|c|}{ Gadījumu skaits } \\
\hline Piederības dimensijas & Nesvērti dati & Svaroti dati \\
\hline 1. klasteris. Integrējušies mītnes zemē, cieši piederīgi Latvijai un latviskajam & 533 & 468 \\
\hline 2. klasteris. Pilnībā integrējušies mītnes zemē, atsvešinājušies no Latvijas un latviskā & 172 & 218 \\
\hline 3. klasteris. Vāji integrējušies mītnes zemē, mēreni piederīgi Latvijai un latviskajam & 109 & 126 \\
\hline 4. klasteris. Vāji integrējušies mītnes zemē, cieši piederīgi Latvijai un latviskajam & 92 & 113 \\
\hline
\end{tabular}

2. tabula. Individuālo izmaiṇu piederības izjūtās ietekmējošie faktori (2014-2019), loğistiskās regresijas rezultāti

\begin{tabular}{|c|c|c|c|c|c|c|}
\hline & \multicolumn{2}{|c|}{$\begin{array}{c}\text { Vājinājusies piederības } \\
\text { izjūta Latvijai un } \\
\text { latviskajam }\end{array}$} & \multicolumn{2}{|c|}{$\begin{array}{c}\text { Pastiprinājusies } \\
\text { piederības izjūta Latvijai } \\
\text { un latviskajam }\end{array}$} & \multicolumn{2}{|c|}{$\begin{array}{l}\text { Pastiprinājusies } \\
\text { piederības izjūta } \\
\text { mītnes zemei un tās } \\
\text { iedzīvotājiem }\end{array}$} \\
\hline & B & $\operatorname{Exp}(B)$ & B & $\operatorname{Exp}(B)$ & B & $\operatorname{Exp}(B)$ \\
\hline Dzimums: vīrieši & & & $1,635 * * *$ & 5,131 & & \\
\hline \multicolumn{7}{|c|}{ Vecumgrupas (atsauces kat. 55+) } \\
\hline $15-24$ & $3,875 * *$ & 48,181 & 0,427 & 1,533 & $3,498 * *$ & 33,065 \\
\hline $25-34$ & $1,813^{*}$ & 6,127 & $-0,149$ & 0,861 & $2,585 * *$ & 13,261 \\
\hline $35-54$ & $2,364 * *$ & 10,633 & 0,146 & 1,157 & $1,564 *$ & 4,776 \\
\hline \multicolumn{7}{|c|}{ Izglītības līmenis (atsauces kat. augsts) } \\
\hline Zems & $2,856 * *$ & 17,395 & $-6,018 * *$ & 0,002 & $-2,191 * *$ & 0,112 \\
\hline Vidējs & $-0,248$ & 0,780 & $-0,229$ & 0,796 & $-0,529$ & 0,589 \\
\hline
\end{tabular}




\begin{tabular}{|c|c|c|c|c|c|c|}
\hline & \multicolumn{2}{|c|}{$\begin{array}{c}\text { Vājinājusies piederības } \\
\text { izjūta Latvijai un } \\
\text { latviskajam }\end{array}$} & \multicolumn{2}{|c|}{$\begin{array}{c}\text { Pastiprinājusies } \\
\text { piederības izjūta Latvijai } \\
\text { un latviskajam }\end{array}$} & \multicolumn{2}{|c|}{$\begin{array}{c}\text { Pastiprinājusies } \\
\text { piederības izjūta } \\
\text { mītnes zemei un tās } \\
\text { iedzīvotājiem }\end{array}$} \\
\hline & B & $\operatorname{Exp}(B)$ & B & $\operatorname{Exp}(B)$ & B & $\operatorname{Exp}(B)$ \\
\hline \multicolumn{7}{|c|}{ Emigrācijas vilnis (atsauces kat. pēc 2011. g.) } \\
\hline Visu mūžu ārpus LV & 2,032 & 7,629 & $-3,627^{*}$ & 0,027 & $-2,262 *$ & 0,104 \\
\hline Pirms 1991.g. & 1,074 & 2,928 & 0,207 & 1,230 & $-0,927$ & 0,396 \\
\hline 1991.-1999. g. & $-0,917$ & 0,400 & $-0,387$ & 0,679 & $-0,908$ & 0,403 \\
\hline 2000.-2003. g. & $-2,259 * *$ & 0,104 & $-1,868 * *$ & 0,154 & 0,865 & 2,375 \\
\hline 2004.-2008. g. & $-0,750$ & 0,472 & $-0,421$ & 0,656 & $-0,007$ & 0,993 \\
\hline 2009.-2011.g. & $-1,100^{* *}$ & 0,333 & $-0,403$ & 0,669 & $-0,649$ & 0,522 \\
\hline \multicolumn{7}{|l|}{ Tautība (atsauces kat. cita) } \\
\hline Latvieši & $2,031 * *$ & 7,624 & $-0,853$ & 0,426 & $-0,266$ & 0,766 \\
\hline Krievi & 0,069 & 1,072 & $-2,358 * * *$ & 0,095 & $-1,306^{*}$ & 0,271 \\
\hline \multicolumn{7}{|c|}{ Sarunvaloda mājās (atsauces kat. latviešu) } \\
\hline Krievu & $1,160 *$ & 3,188 & 0,520 & 1,682 & 0,604 & 1,830 \\
\hline Latviešu un krievu & $-1,542 *$ & 0,214 & 1,168 & 3,215 & $1,702 * *$ & 5,484 \\
\hline Cita, t. sk. mītnes zemes & 0,593 & 1,810 & $1,487 * *$ & 4,426 & $-0,654$ & 0,520 \\
\hline Pilsonība: Latvijas & $-0,444$ & 0,642 & $-1,095$ & 0,335 & $-0,285$ & 0,752 \\
\hline Pilsonība: mītnes zemes & $0,903 *$ & 2,468 & 0,520 & 1,682 & 0,181 & 1,199 \\
\hline $\begin{array}{l}\text { Latvijā dzīvo kāds no vecāku } \\
\text { gimenes (māte, tēvs, māsa, } \\
\text { brālis u. c.) }\end{array}$ & $-1,060^{*}$ & 0,346 & $0,466^{*}$ & 1,594 & 0,394 & 1,484 \\
\hline $\begin{array}{l}\text { Latvijā dzīvo kāds no respon- } \\
\text { denta gimenes (vīrs, sieva, } \\
\text { bērni) }\end{array}$ & $-0,774$ & 0,461 & $1,097 * *$ & 2,995 & $1,806^{* * *}$ & 6,085 \\
\hline $\begin{array}{l}\text { Latvijā nedzīvo neviens } \\
\text { radinieks }\end{array}$ & 0,322 & 1,380 & 0,556 & 1,744 & $-1,000$ & 0,368 \\
\hline Latvijā dzīvo draugi & $-0,958$ & 0,384 & $0,434 *$ & 1,544 & 0,269 & 1,309 \\
\hline Latvijā nav draugu & $-2,347^{*}$ & 0,096 & 1,178 & 3,248 & 1,386 & 3,999 \\
\hline $\begin{array}{l}\text { Draugi no Latvijas dzīvo mītnes } \\
\text { zemē }\end{array}$ & $-1,074 * *$ & 0,342 & 0,327 & 1,387 & $-0,551$ & 0,577 \\
\hline Draugi dzimuši mītnes zemē & $-0,473$ & 0,623 & $-0,221$ & 0,802 & $-0,311$ & 0,733 \\
\hline $\begin{array}{l}\text { Draugi ir iebraucēji mītnes } \\
\text { zemē }\end{array}$ & 0,530 & 1,699 & $-0,998 * *$ & 0,369 & $-0,156$ & 0,856 \\
\hline Latvijā ir īpašums & 0,107 & 1,113 & $0,933 * * *$ & 2,542 & $-0,355$ & 0,701 \\
\hline $\begin{array}{l}\text { Mītnes zemē ir, kam palīizzēt, } \\
\text { ja saslimtu }\end{array}$ & $-4,028 * * *$ & 0,018 & 0,341 & 1,406 & $3,381 * * *$ & 29,408 \\
\hline $\begin{array}{l}\text { Mītnes zemē ir, kam palīdzēt, ja } \\
\text { jāaizṇemas nauda }\end{array}$ & 0,435 & 1,545 & $1,675^{* *}$ & 5,338 & $-0,077$ & 0,926 \\
\hline $\begin{array}{l}\text { Mītnes zemē ir, ar ko parunāt, } \\
\text { ja noskumis }\end{array}$ & $2,846^{* *}$ & 17,220 & 0,655 & 1,925 & 0,485 & 1,625 \\
\hline $\begin{array}{l}\text { Dzīvo pārmaiņus Latvijā un } \\
\text { ārzemēs }\end{array}$ & $-2,732 * * *$ & 0,065 & 0,433 & 1,541 & $-1,371^{* *}$ & 0,254 \\
\hline $\begin{array}{l}\text { Nodarbošanās: strādā algotu } \\
\text { darbu }\end{array}$ & $-1,225^{* *}$ & 0,294 & $-1,591 * * *$ & 0,204 & $0,946^{*}$ & 2,574 \\
\hline $\begin{array}{l}\text { Nodarbošanās: uzṇēmējs, } \\
\text { pašnodarbinātais }\end{array}$ & $-0,328$ & 0,721 & $-0,746$ & 0,474 & $1,251 * *$ & 3,494 \\
\hline Nodarbošanās: mācās/studē & 0,725 & 2,066 & $-1,023$ & 0,359 & 0,725 & 2,065 \\
\hline $\begin{array}{l}\text { Nodarbošanās: bērna kopšanas } \\
\text { atvaḷinājumā }\end{array}$ & $-1,627 * *$ & 0,197 & $-0,689$ & 0,502 & $1,231 * *$ & 3,426 \\
\hline Nodarbošanās: pensija & $-3,315 * *$ & 0,036 & $-2,602 * *$ & 0,074 & 1,911 & 6,761 \\
\hline Nodarbošanās: cita & $-0,221$ & 0,802 & 0,684 & 1,981 & $3,319 * * *$ & 27,629 \\
\hline
\end{tabular}




\begin{tabular}{|c|c|c|c|c|c|c|}
\hline & \multicolumn{2}{|c|}{$\begin{array}{c}\text { Vājinājusies piederības } \\
\text { izjūta Latvijai un } \\
\text { latviskajam }\end{array}$} & \multicolumn{2}{|c|}{$\begin{array}{c}\text { Pastiprinājusies } \\
\text { piederības izjūta Latvijai } \\
\text { un latviskajam }\end{array}$} & \multicolumn{2}{|c|}{$\begin{array}{c}\text { Pastiprinājusies } \\
\text { piederības izjūta } \\
\text { mītnes zemei un tās } \\
\text { iedzīvotājiem }\end{array}$} \\
\hline & \begin{tabular}{l|l} 
B & \\
\end{tabular} & $\operatorname{Exp}(B)$ & B & $\operatorname{Exp}(B)$ & B & $\operatorname{Exp}(B)$ \\
\hline \multicolumn{7}{|c|}{ Materiālā pārticība: kā izdodas tikt galā ar ikdienas izdevumiem (atsauces kat. l̦oti viegli) } \\
\hline Ar lielām grūtībām & $3,278^{*}$ & 26,514 & $-18,634$ & 0,000 & $-0,269$ & 0,764 \\
\hline Ar grūtībām & $-1,258$ & 0,284 & $-20,466$ & 0,000 & $-1,744$ & 0,175 \\
\hline Ar nelielām grūtībām & $-1,660 * *$ & 0,190 & $-0,695$ & 0,499 & $-1,133^{*}$ & 0,322 \\
\hline Samērā viegli & 0,031 & 1,032 & $-1,136^{*}$ & 0,321 & $-0,225$ & 0,799 \\
\hline Viegli & $0,928 * *$ & 2,530 & $0,363 *$ & 1,437 & $-0,913 * *$ & 0,401 \\
\hline $\begin{array}{l}\text { Apmierinātība ar dažādām dzī- } \\
\text { ves sfērām: apmierināti ar visu }\end{array}$ & $0,865^{*}$ & 2,375 & $-0,182$ & 0,833 & $-0,262$ & 0,769 \\
\hline $\begin{array}{l}\text { Mājsaimniecība: dzīvo kopā ar } \\
\text { savu ǵimeni }\end{array}$ & 0,664 & 1,942 & $-1,492$ & 0,225 & $-3,587 * * *$ & 0,028 \\
\hline $\begin{array}{l}\text { Mājsaimniecība: dzīvo kopā ar } \\
\text { saviem vecākiem }\end{array}$ & $1,452 *$ & 4,273 & $-0,522$ & 0,594 & $-0,541$ & 0,582 \\
\hline $\begin{array}{l}\text { Mājsaimniecība: dzīvo kopā ar } \\
\text { citiem cilvēkiem }\end{array}$ & $-0,476$ & 0,621 & $-2,185^{* *}$ & 0,113 & $-1,462 *$ & 0,232 \\
\hline $\begin{array}{l}\text { Mājsaimniecība: dzīvo viens } \\
\text { pats }\end{array}$ & 0,306 & 1,358 & $-2,079 * *$ & 0,125 & $-2,523 * *$ & 0,080 \\
\hline $\begin{array}{l}\text { Līdzdalība diasporas orga- } \\
\text { nizācijās un kolektīvos }\end{array}$ & $-2,290 * * *$ & 0,101 & & & $-1,332 * * *$ & 0,264 \\
\hline Konstante & $-0,033$ & 0,968 & 0,895 & 2,446 & $-0,938$ & 0,391 \\
\hline
\end{tabular}

$* * * p<0,001, * * p<0,01, * p<0,05$

Piezīme: analīze neietver tos respondentus, kuri 2019. gadā atgriezušies Latvijā, - remigrantus. 